\title{
KAJIAN SIFAT FISIK, KIMIA, DAN SENSORIS SAMBAL TEMPOYAK (DURIAN TERFERMENTASI) BERKEMASAN RETORT POUCH
}

\author{
Hesti Ayuningtyas Pangastuti, Lasuardi Permana, Dea Tio Mareta, Vita Fitriani, \\ dan Amalia Wahyuningtyas \\ Program Studi Teknologi Pangan, Jurusan Teknologi Produksi dan Industri, Institut Teknologi Sumatera \\ Email: hesti.pangastuti@tp.itera.ac.id
}

\begin{abstract}
ABSTRAK
Tempoyak merupakan daging fermentasi durian yang diproses, dengan atau tanpa menggunakan garam. Tempoyak dapat divariasi menjadi berbagai olahan produk pangan, salah satunya adalah sambal tempoyak. Komersialisasi sambal tempoyak dapat dilakukan untuk meningkatkan umur simpan produk, salah satunya dengan menggunakan pengemasan retort. Penelitian ini bertujuan untuk mengetahui pengaruh penambahan asam sitrat ke dan perbedaan waktu sterilisasi terhadap sifat fisikokimia dan sensoris sambal tempoyak dengan pengemasan retort untuk menghasilkan produk dengan kombinasi perlakuan terbaik. Hasil penelitian menunjukkan bahwa interaksi penambahan asam sitrat dan perbedaan waktu sterilisasi memiliki pengaruh signifikan $(\mathrm{p}<0.05)$ terhadap parameter kadar air, $\mathrm{pH}$, aktivitas air, viskositas, dan kecerahan pada produk. Setelah dilakukan teknik eliminasi menggunakan metode indeks efektivitas serta dilakukan evaluasi sensoris, diketahui bahwa perlakuan sambal tempoyak terbaik adalah produk dengan penambahan $3 \%$ asam sitrat dan waktu sterilisasi 35 menit.

Kata kunci-pengemasan; retort; sambal; tempoyak
\end{abstract}

\section{PENDAHULUAN}

Tempoyak adalah daging durian (Durio zibethinus) yang difermentasi baik menggunakan atau tanpa menggunakan garam. Produk pangan ini merupakan bahan masakan yang sering digunakan di bagian barat Indonesia, mulai dari Lampung, Sumatera Selatan, Bengkulu, Jambi, Sumatera Barat, Aceh, dan Kalimantan Barat (Widawati dan Efrianti, 2015), juga di sebagian wilayah di Malaysia. Produk pangan ini juga dikenal di Malaysia (Leisner et al., 2001). Total keasaman tempoyak adalah 3,6\% sebagai asam asetat dengan $\mathrm{pH}$ sekitar 4,60-6,59 (Yuliana, 2007). Tempoyak umumnya dimakan dalam bentuk segar bersama nasi, maupun dijadikan campuran dalam sajian lain (Gandjar, 2000).

Pembuatan tempoyak memiliki resep khas yang berbeda-beda sesuai dengan daerahnya. Tempoyak dari Sumatera, misalnya, berbeda dengan tempoyak Kalimantan. Pada tempoyak Sumatera, penambahan garam dilakukan pada proses fermentasi, sedangkan tempoyak Kalimantan melibatkan penambahan garam dan gula (Yulistiani dkk, 2014). Pembuatan tempoyak dapat dilakukan melalui fermentasi spontan maupun menggunakan ragi, namun sebagian besar masyarakat menggunakan fermentasi spontan dalam pembuatannya (Yuliana, 2007). Salah satu produk olahan tempoyak adalah sambal tempoyak. Sambal tempoyak kerap dijadikan makanan sehari-hari maupun pada kesempatan hajatan dalam adat perkawinan atau sunatan (Rasyid, 2004). Eratnya sambal tempoyak dalam budaya masyarakat Sumatera mendorong adanya peluang komersialisasi. Sayangnya, hingga saat ini belum ada bentuk komersialisasi dalam produk sambal tempoyak. Untuk itu, diperlukan inovasi produk agar sambal dapat dipromosikan lebih luas.

Inovasi pengemasan telah banyak dilakukan, terutama melalui teknologi retort (Bindu et al., 2005; Al-Baali dan Farid, 2006; Rajan et al., 2014). Teknologi retort menjadi pilihan karena memiliki kelebihan dari segi penampilan, kepraktisan, dan umur simpan (Holanda et al., 2018; Topno et al., 2011; Apichartsrangkoon et al., 2012). Hasil penelitian Robertson (2006) menunjukkan bahwa produk retort yang disimpan pada suhu $27^{\circ} \mathrm{C}$ dapat bertahan selama 76 bulan.

Peningkatan umur simpan juga dapat dilakukan dengan penambahan asam sitrat. Selain dapat menurunkan $\mathrm{pH}$ sehingga dapat memperpanjang umur simpan produk, penggunaan asam lemah, misalnya asam sitrat, juga dapat mencegah terjadinya pencoklatan enzimatis dan non-enzimatis (Chaethong dan Ponsawatmanit, 2015). Asam sitrat merupakan salah satu antioksidan yang paling banyak digunakan di dunia (Manolopoulou dan Varzakas, 2011). Senyawa tersebut merupakan agen 
pengkelat yang bekerja dengan menghambat enzim polifenol oksida (PPO) (Jiang et al, 1999; RojasGrau et al., 2008).

Dalam penelitian ini, akan dicari tahu mengeni pengaruh lama sterilisasi dan penambahan asam sitrat terhadap karakteristik fisik, kimia, dan sensoris sambal tempoyak yang dikemas dalam retort pouch, sehingga akan didapatkan formula sambal tempoyak terbaik.

\section{METODOLOGI PENELITAN}

\section{A. Waktu dan Tempat}

Penelitian dilaksanakan pada bulan April-Desember 2019 di Laboratorium Kimia Institut Teknologi Sumatera, Laboratorium Teknologi Hasil Pertanian Politeknik Negeri Lampung, dan Laboratorium Rekayasa Proses Pengolahan Pangan Universitas Gadjah Mada. Pembuatan produk dan analisis sensoris dilakukan di Institut Teknologi Sumatera. Analisis kadar air, pH, dan aktivitas air dilaksanakan di Politeknik Negeri Lampung, sedangkan analisis viskositas dan warna dilaksanakan di Universitas Gadjah Mada.

\section{B. Bahan dan Peralatan}

Bahan yang digunakan dalam pembuatan produk sambal tempoyak adalah durian, cabai merah, cabai rawit merah, bawang putih, bawang merah, air, gula, garam, minyak goreng, asam sitrat, dan kemasan retort pouch aluminium foil ukuran $20 \mathrm{~cm}$ x $20 \mathrm{~cm}$ (ketebalan 120 mikron). Komposisi bahan dalam pembuatan sambal tempoyak dijelaskan pada Tabel 1. Bahan yang digunakan untuk analisis produk selama penelitian antara lain aquades dan larutan buffer natrium fosfat $\mathrm{pH} 3$ dan 9 (Smart Lab, Indonesia).

Alat yang digunakan untuk analisis antara lain timbangan (Ohaus, USA), oven (Memmert, Germany), pH meter (Hanna, Germany), chromameter (Konica Minolta CR-400), viskometer (Brookfield DV-1, AMETEK, USA), Aw meter (Pawkit, Decagon, USA), dan booth uji sensoris.

\begin{tabular}{ll} 
Tabel 1. Komposisi Pembuatan Sambal Tempoyak \\
\hline Komposisi & Persentase $(\%)$ \\
\hline Cabai merah & 6 \\
Cabai rawit & 2 \\
Bawang putih & 5 \\
Bawang merah & 10 \\
Tempoyak & 47 \\
Gula & 0,5 \\
Garam & 0,5 \\
Air & 29 \\
\hline
\end{tabular}

\section{Prosedur Penelitian}

Penelitian dilakukan menggunakan Rancangan Acak Lengkap Faktorial (RAL Faktorial) yang terdiri dari dua faktor, yaitu penambahan konsentrasi asam sitrat dan lama sterilisasi. Faktor pertama, yaitu lama sterilisasi terdiri dari 2 taraf faktor, yaitu 20 menit dan 35 menit, sedangkan faktor kedua yaitu konsentrasi asam sitrat terdiri dari 3 taraf faktor, yaitu dengan kadar sebesar 0,1\%; 0,3\% dan $0,5 \%$ (bb).

Pembuatan tempoyak dilakukan dengan metode Amin et al. (2004) dengan modifikasi. Durian yang digunakan adalah durian berkualitas baik dan matang dengan daging buah berwarna kuning. Daging durian ditambah 3\% garam dan 1\% gula selapis demi selapis, kemudian diletakkan ke dalam kontainer tertutup pada suhu ruang selama 72 jam.

Pembuatan sambal tempoyak dimulai dari pengukusan cabai merah, cabai rawit merah, bawang merah, dan bawang putih pada suhu $80^{\circ} \mathrm{C}$ selama 2 menit. Penghalusan cabai dilakukan bersamaan dengan pencampuran dengan tempoyak yang telah dibuat sebelumnya. Proses pemanasan disertai pengadukan kemudian dilakukan pada bahan selama 30 menit. Sambal dilakukan proses pendinginan hingga suhu $75^{\circ} \mathrm{C}$, dilanjutkan dengan penambahan asam sitrat sesuai konsentrasi perlakuan. Pengemasan dengan retort pouch dilakukan secara sempurna tanpa adanya delaminasi dan kerut. Setelah dikemas, sampel kemudian disterilisasi pada suhu $121^{\circ} \mathrm{C}$ dengan dua variabel waktu $(20$ menit 
dan 35 menit) menggunakan sterilizator uap bertekanan tinggi (Tomy SX-500, Japan), lalu dilanjutkan dengan pendinginan cepat pada air mengalir. Produk sambal tempoyak kemasan retort pouch kemudian dianalisis bertahap sesuai desain penelitian.

\section{Prosedur Analisis}

Analisis sifat kimia yang dilakukan adalah kadar air dan $\mathrm{pH}$. Kadar air dianalisis dengan metode AOAC (2000), sedangkan analisis pH dilakukan dengan pH meter (Starter 3000, OHAUS, USA). Analisis sifat fisik yang dilakukan dalam penelitian ini adalah aktivitas air, viskositas, dan warna. Pengujian aktivitas air dilakukan dengan Aw meter (Pawkit, Decagon, USA), viskositas menggunakan viskometer (Model RVT Serial 105202, Brookfield, USA), serta warna menggunakan colorimeter (CR-400, Konica Minolta, Japan). Perubahan warna yang diukur meliputi L (tingkat kecerahan $)$, koordinat $\mathrm{a}(+\mathrm{a}=$ merah, $-\mathrm{a}=$ hijau $)$, dan koordinat $\mathrm{b}(+\mathrm{b}=$ kuning, $-\mathrm{b}=\mathrm{biru})$.

\section{Pemilihan Perlakuan Terbaik}

Sambal dengan kombinasi perlakuan terbaik dianalisis menggunakan metode indeks efektivitas DeGarmo et al. (1984). Pemilihan dilakukan untuk mempersempit 8 (delapan) kombinasi perlakuan menjadi 2 (dua) kombinasi perlakuan sambal terbaik yang akan dilanjutkan ke tahap kedua, yaitu uji sensoris. Metode indeks efektivitas adalah metode pembobotan dimana setiap parameter yang diukur akan ditimbang sesuai tingkat kepentingannya. Tingkat kepentingan dalam setiap parameter dijelaskan pada Tabel 2.

Tabel 2. Tingkat Kepentingan dalam Uji Indeks Efektivitas

\begin{tabular}{ll}
\hline Parameter & Bobot Nilai \\
\hline Kadar air & 1 \\
pH & 0,9 \\
Aktivitas air & 0,3 \\
Viskositas & 0,6 \\
Tingkat kecerahan (L) & 0,6 \\
Koordinat a & 0,6 \\
Koordinat b & 0,6 \\
\hline
\end{tabular}

\section{Analisis Sensoris}

Analisis sensoris dilakukan pada 35 panelis menggunakan uji hedonik (Lim, 2011). Analisis sensoris dilakukan dengan menguji sambal kontrol (sambal tempoyak tanpa sterilisasi dan tanpa asam sitrat), dan sambal dengan sterilisasi (sambal tempoyak tanpa asam sitrat) ditambah dengan dua sambal perlakuan terbaik yang didapat dari metode indeks efektivitas. Variabel pengamatan pada uji sensoris meliputi warna, tekstur, aroma, rasa, dan keseluruhan secara umum dengan menggunakan skor 1 sampai $9(1=$ amat sangat tidak suka, $2=$ sangat tidak suka, $3=$ tidak suka, $4=$ agak tidak suka, $5=$ netral, $6=$ agak suka, $7=$ suka, $8=$ sangat suka, $9=$ amat sangat suka).

\section{Analisis Statistik}

Data penelitian utama, yaitu pengaruh kombinasi penambahan asam sitrat dan lama sterilisasi pada sambal tempoyak dianalisis menggunakan program SPSS menggunakan Two-Way ANOVA dengan lama sterilisasi dan penambahan asam sitrat sebagai faktor dan dilanjutkan uji Duncan Multiple Range Test (DMRT) dengan taraf kepercayaan 95\% ( $\mathrm{p}<0,05)$. Pada data uji sensoris, dilakukan analisis menggunakan One-Way ANOVA dan dilanjutkan uji DMRT dengan taraf kepercayaan yang sama $(95 \%)$.

\section{HASIL DAN PEMBAHASAN}

\section{A. Kadar Air}

Hasil penelitian (Tabel 3) menunjukkan pengaruh signifikan pada penambahan asam sitrat, lama sterilisasi, serta interaksinya terhadap kadar air pada sambal berkemasan retort. Air dapat bekerja sebagai katalis dalam kaitannya dengan aktivitas biokimia bakteri, meskipun kadar air tidak cukup akurat dalam menerangkan stabilitas produk (Fellows, 2000). Nilai kadar air dalam penelitian 
ini berkisar antara 64,39-86,04\%, tidak jauh berbeda dengan sambal dalam penelitian lain, yaitu $72,63-93,02 \%$ (Zain et al., 2010). Selama proses retort, kadar air sampel menurun signifikan $(\mathrm{p}<0.05)$ seiring dengan peningkatan lama sterilisasi, dimana hal ini serupa dengan penelitian Pal et al. (2018). Kadar air terendah terdapat pada sambal andaliman dengan perlakuan sterilisasi 35 menit dan asam sitrat $1 \%$ yaitu sebesar $64,39 \%$.

\section{B. Nilai pH}

Data (Tabel 3) menunjukkan bahwa terdapat perbedaan signifikan pada sambal tempoyak dengan penambahan asam sitrat, lama sterilisasi, serta interaksinya terhadap nilai $\mathrm{pH}$. Sambal tempoyak dalam penelitian ini memiliki $\mathrm{pH}$ yang tergolong rendah, yaitu 3,40-4,62. Rendahnya nilai $\mathrm{pH}$ disebabkan akibat adanya aktivitas mikroorganisme dalam fermentasi tempoyak yang menghasilkan asam laktat, asam asetat, asam malat, dan asam propionat (Chuah et al., 2016; Yuliana, 2005), dengan daerah pH tempoyak antara 3,96-4,08 (Amin et al., 2004). Bakteri asam laktat merupakan mikroorganisme dominan dalam kondisi ini (Leisner et al., 2001). Asam asetat yang ditambahkan ke dalam produk juga memiliki pengaruh dalam menghasilkan penurunan $\mathrm{pH}$, serupa dengan penelitian Chaethong dan Ponsawatmanit (2015). Peningkatan waktu sterilisasi dapat menurunkan nilai $\mathrm{pH}$ (Jannah dkk, 2018). Nilai pH yang rendah akan menguntungkan dari segi umur simpan, karena akan menghambat pertumbuhan mikroorganisme. Efek nilai $\mathrm{pH}$ dalam menghambat pertumbuhan mikroorganisme dapat bersinergi dengan aktivitas air produk (Robertson, 2009).

\section{Aktivitas Air}

Penambahan asam sitrat, lama sterilisasi dan interaksi antara asam sitrat dan lama sterilisasi memberikan pengaruh signifikan terhadap aktivitas air (Tabel 3). Nilai aktivitas air pada sambal yang diteliti berada pada daerah 0,87-0,92. Nilai ini dapat disebabkan oleh kontribusi aktivitas air pada bahan baku tempoyak, yaitu pada 0,83-0,85 (Yulistiani dkk, 2014). Aktivitas air yang tinggi akan menurunkan umur simpan produk karena mempermudah pertumbuhan mikroba. Bakteri penyakit bawaan makanan (foodborne disease) akan tumbuh pada bahan pangan dengan aktivitas air di atas 0,85 (Sevenich et al., 2015). Aktivitas air terbaik terdapat pada sambal dengan lama sterilisasi 20 menit dan asam sitrat $5 \%$.

\section{Viskositas}

Hasil nilai viskositas menunjukkan bahwa viskositas dipengaruhi oleh berbagai penambahan asam sitrat, lama sterilisasi, serta interaksinya. Peningkatan waktu sterilisasi akan meningkatkan viskositas. Hal tersebut terjadi karena adanya perlakuan panas dapat mempercepat terjadinya oksidasi. Oksidasi produk, termasuk aldehid, keton, hidrokarbon, dan senyawa polimer lainnya dapat menyebabkan perubahan viskositas (Sahin dan Sumnu, 2009). Penurunan viskositas bersamaan dengan penambahan konsentrasi asam sitrat pada sambal dengan waktu sterilisasi 20 menit dapat disebabkan karena peran asam sitrat yang bersifat antioksidan secara tidak langsung melalui kelasi ion logam yang mengkatalisis oksidasi (Sun, 2014).

\section{E. Warna}

Parameter warna menunjukkan bahwa penambahan asam sitrat, lama sterilisasi, serta interaksinya mempengaruhi tingkat kecerahan sambal tempoyak berkemasan retort (Tabel 4). Namun, hal tersebut tidak mempengaruhi koordinat a dan b. Penurunan tingkat kecerahan pada sambal tempoyak diduga terjadi karena destruksi pigmen karotenoid. Karotenoid terdapat dalam durian sebagai betakaroten (Voon et al., 2006), sedangkan pada cabai merah ada dalam bentuk senyawa capsanthin dan capsurobin (Pugliese et al., 2013). Selain destruksi pigmen, degradasi warna dapat terjadi akibat browning non-enzimatis berupa reaksi Maillard pada saat proses retort terjadi (Inchuen et al., 2011). 
Tabel 3. Pengaruh Lama Sterilisasi dan Penambahan Asam Sitrat terhadap Kadar Air, pH, Aktivitas Air, dan Viskositas Sambal Tempoyak

\begin{tabular}{|c|c|c|c|c|c|c|c|c|c|}
\hline \multirow{2}{*}{ Parameter } & \multicolumn{8}{|c|}{ Lama sterilisasi } & $\begin{array}{l}\text { Pengaruh } \\
\text { signifikan }\end{array}$ \\
\hline & Grup 1 & Grup 2 & Grup 3 & Grup 4 & Grup 1 & Grup 2 & Grup 3 & Grup 4 & \\
\hline Kadar air & $\begin{array}{ll}75,31^{\mathrm{b}} \quad \pm \\
4,33\end{array}$ & $85,45^{\mathrm{c}} \pm 4,56$ & $86,04^{\mathrm{c}} \pm 2,99$ & $85,83^{c} \pm 8,36$ & $64,79^{\mathrm{a}} \pm 5,87$ & $64,39^{\mathrm{a}} \pm 5,78$ & $64,82^{a} \pm 3,60$ & $64,71^{\mathrm{a}} \pm 3,05$ & $\mathrm{~S}, \mathrm{~A}, \mathrm{I}$ \\
\hline $\mathrm{pH}$ & $4,61^{\mathrm{g}} \pm 0,03$ & $4,62^{\mathrm{g}} \pm 0,12$ & $4,29^{\mathrm{f}} \pm 0,14$ & $4,14^{\mathrm{e}} \pm 0,09$ & $3,54^{\mathrm{d}} \pm 0,15$ & $3,46^{\mathrm{c}} \pm 0,27$ & $3,32^{\mathrm{a}} \pm 0,33$ & $3,40^{\mathrm{b}} \pm 0,11$ & $\mathrm{~S}, \mathrm{~A}, \mathrm{I}$ \\
\hline $\begin{array}{l}\text { Aktivitas } \\
\text { air }\end{array}$ & $0,89^{\mathrm{c}} \pm 0,00$ & $0,88^{\mathrm{b}} \pm 0,00$ & $0,88^{\mathrm{b}} \pm 0,00$ & $0,87^{\mathrm{a}} \pm 0,00$ & $0,90^{\mathrm{cd}} \pm 0,01$ & $0,88^{\mathrm{ab}} \pm 0,01$ & $0,90^{\mathrm{d}} \pm 0,00$ & $0,92^{\mathrm{e}} \pm 0,00$ & $\mathrm{~S}, \mathrm{~A}, \mathrm{I}$ \\
\hline
\end{tabular}

$\mathrm{S}=$ pengaruh utama lama sterilisasi $(\mathrm{P}<0,05) ; \mathrm{A}=$ pengaruh utama penambahan asam sitrat $(\mathrm{P}<0,05) ; \mathrm{I}=$ interaksi antara lama sterilisasi dan penambahan asam sitrat $(\mathrm{p}<0,05)$. Huruf yang sama pada baris yang sama menunjukkan bahwa tidak ada perbedaan signifikan ( $>00,05)$. Grup $1-$ penambahan asam sitrat $0 \%$, grup 2 - penambahan asam sitrat $1 \%$, grup 3 - penambahan asam sitrat $3 \%$, grup 4 - penambahan asam sitrat $5 \%$.

Tabel 4. Pengaruh Lama Sterilisasi dan Penambahan Asam Sitrat terhadap Warna Sambal Tempoyak

\begin{tabular}{|c|c|c|c|c|c|c|c|c|c|}
\hline \multirow{2}{*}{ Parameter } & \multicolumn{8}{|l|}{ Lama sterilisasi } & $\begin{array}{l}\text { Pengaruh } \\
\text { signifikan }\end{array}$ \\
\hline & Grup 1 & Grup 2 & Grup 3 & Grup 4 & Grup 1 & Grup 2 & Grup 3 & Grup 4 & \\
\hline $\begin{array}{l}\text { Tingkat } \\
\text { kecerahan }(\mathrm{L})\end{array}$ & $42,04^{\mathrm{a}} \pm 4,40$ & $45,82^{\mathrm{d}} \pm 3,21$ & $47,62^{\mathrm{e}} \pm 3,11$ & $\begin{array}{l}43,88^{\mathrm{bc}} \quad \pm \\
4,18\end{array}$ & $\begin{array}{l}44,60^{\text {cd }} \\
3,99\end{array}$ & $\begin{array}{l}43,89^{\mathrm{bc}} \\
4,17\end{array}$ & $\begin{array}{l}42,55^{\mathrm{ab}} \\
3,89\end{array}$ & $\begin{array}{l}44,51^{\text {cd }} \\
3,61\end{array}$ & $\mathrm{~S}, \mathrm{~A}, \mathrm{I}$ \\
\hline Koordinat a* & $20,27 \pm 1,07$ & $15,77 \pm 0,99$ & $17,63 \pm 1,11$ & $16,07 \pm 0,43$ & $18,40 \pm 0,76$ & $17,21 \pm 0,85$ & $16,15 \pm 1,55$ & $18,07 \pm 1,80$ & NS \\
\hline Koordinat $b^{*}$ & $36,00^{\mathrm{ab}} \pm 2,98$ & $36,24^{\mathrm{ab}} \pm 3,10$ & $37,08^{b} \pm 1,55$ & $28,21^{\mathrm{a}} \pm 1,99$ & $\begin{array}{ll}32,62^{\mathrm{ab}} & \pm \\
2,05 & \end{array}$ & $\begin{array}{ll}32,77^{\mathrm{ab}} & \pm \\
2,07 & \end{array}$ & $\begin{array}{ll}31,51^{\mathrm{ab}} \quad \pm \\
3,07\end{array}$ & $\begin{array}{ll}35,08^{\mathrm{ab}} & \pm \\
2.22 & \end{array}$ & NS \\
\hline
\end{tabular}

$\mathrm{S}=$ pengaruh utama lama sterilisasi $(\mathrm{P}<0,05) ; \mathrm{A}=$ pengaruh utama penambahan asam sitrat $(\mathrm{P}<0,05) ; \mathrm{I}=$ interaksi antara lama sterilisasi dan penambahan asam sitrat $(\mathrm{p}<0,05)$; NS = tidak ada yang signifikan. Huruf yang sama pada baris yang sama menunjukkan bahwa tidak ada perbedaan signifikan $(\mathrm{p}>0,05)$. Grup 1 - penambahan asam sitrat $0 \%$, grup 2 - penambahan asam sitrat $1 \%$, grup 3 - penambahan asam sitrat 3\%, grup 4 - penambahan asam sitrat $5 \%$. 


\section{F. Pemilihan Sampel Terbaik}

Pemilihan sampel terbaik dianalisis menggunakan metode indeks efektivitas (DeGarmo et al., 1984). Hasil pemilihan sampel yang digambarkan pada Tabel 5 menunjukkan bahwa dua sambal retort terbaik dari seluruh parameter adalah: (1) sambal dengan penambahan asam sitrat 3\%, lama sterilisasi 35 menit; dan (2) sambal dengan penambahan asam sitrat 5\%, lama sterilisasi 35 menit. Kedua sambal tersebut dilanjutkan pengukuran uji sensoris bersama dua sambal lainnya, yaitu sambal kontrol dan sambal dengan sterilisasi (tanpa asam sitrat) untuk mengetahui perlakuan sambal yang terbaik.

Tabel 5 Pemilihan Perlakuan Terbaik dengan Metode Indeks Efektivitas

\begin{tabular}{ccc}
\hline Peringkat & Perlakuan & Skor \\
\hline 6 & Asam sitrat 0\%; lama sterilisasi 20 menit & 1,8329 \\
7 & Asam sitrat 1\%; lama sterilisasi 20 menit & 1,2670 \\
5 & Asam sitrat 3\%; lama sterilisasi 20 menit & 1,9575 \\
8 & Asam sitrat 5\%; lama sterilisasi 20 menit & 0,8799 \\
3 & Asam sitrat 0\%; lama sterilisasi 35 menit & 2,8112 \\
3 & Asam sitrat 1\%; lama sterilisasi 35 menit & 3,0521 \\
2 & Asam sitrat 3\%; lama sterilisasi 35 menit & 3,0536 \\
1 & Asam sitrat 5\%; lama sterilisasi 35 menit & 3,4668 \\
\hline
\end{tabular}

Tabel 6 Hasil Evaluasi Sensoris Sambal Andaliman Berkemasan Retort

\begin{tabular}{lcccc}
\hline Parameter & \multicolumn{5}{c}{ Perlakuan } \\
\cline { 2 - 5 } & Kontrol & $\begin{array}{c}\text { Asam sitrat 0\%, } \\
\text { lama sterilisasi 35 } \\
\text { menit }\end{array}$ & $\begin{array}{c}\text { Asam sitrat 3\%, } \\
\text { lama sterilisasi 35 } \\
\text { menit }\end{array}$ & $\begin{array}{c}\text { Asam sitrat 5\%, } \\
\text { lama sterilisasi 35 } \\
\text { menit }\end{array}$ \\
\hline Warna & 7,12 & 6,60 & 6,76 & 6,92 \\
\hline Tekstur & $6,36^{\mathrm{bc}}$ & $5,96^{\mathrm{ab}}$ & $6,52^{\mathrm{c}}$ & $5,48^{\mathrm{a}}$ \\
\hline Aroma & $5,96^{\mathrm{ab}}$ & $5,60^{\mathrm{a}}$ & $6,56^{\mathrm{b}}$ & $5,44^{\mathrm{a}}$ \\
\hline Rasa & 4,48 & 4,56 & 4,20 & 4,04 \\
\hline Overall & $5,48^{\mathrm{a}}$ & $6,28^{\mathrm{b}}$ & $6,24^{\mathrm{b}}$ & $6,12^{\mathrm{b}}$ \\
\hline
\end{tabular}

keterangan: huruf yang berbeda pada baris yang sama menunjukkan bahwa ada perbedaan signifikan $(\mathrm{p}<0,05)$. Tidak adanya huruf pada baris yang sama menunjukkan tidak adanya perbedaan signifikan $(p>0,05)$ antar kelompok.

\section{G. Evaluasi Sensoris}

Pada evaluasi sensoris, empat buah sambal diteliti, yaitu sambal kontrol (tanpa sterilisasi dan penmabahan asam sitrat), sambal dengan sterilisasi (tanpa asam sitrat), serta dua sampel terbaik berdasarkan metode indeks efektivitas, yaitu: (1) sambal dengan penambahan asam sitrat 3\%, lama sterilisasi 35 menit dan (2) sambal dengan penambahan asam sitrat 5\%, lama sterilisasi 35 menit. Hasil evaluasi sensoris pada berbagai sambal tempoyak terpilih (Tabel 6) menunjukkan bahwa parameter tekstur dan rasa tidak berbeda signifikan pada keempat perlakuan sambal yang diteliti. Produk retort memiliki kecenderungan mengalami reaksi Maillard, yang berpotensi pada perubahan flavor dan warna produk (Catauro et al., 2011). Namun, reaksi Maillard diduga belum sepenuhnya terjadi pada produk ini, karena tidak memberikan pengaruh signifikan pada preferensi panelis. Beberapa studi pada produk retort juga menunjukkan tren yang sama, yaitu nilai evaluasi sensoris yang tidak berbeda nyata dibanding produk kontrol (Pal et al., 2018; Kumar et al., 2017). Rasa yang tidak berbeda nyata menurut panelis dapat terjadi karena karakteristik asam sitrat yang memiliki tingkat kegetiran yang relatif clean, berbeda dengan asam lain, misalnya asam cuka yang terasa sepat, atau asam tartarat yang terasa tajam dan pahit (Gardner, 1972; Sausville, 1974).

Tiga parameter lain yang diteliti, yaitu tekstur, aroma, dan overall menunjukkan beda nyata pada keempat perlakuan sambal. Berdasarkan uji lanjut, sambal yang terbaik berdasarkan seluruh parameter ini adalah sambal tempoyak dengan penambahan asam sitrat 3\% dan lama sterilisasi 35 menit. Tempoyak menghasilkan senyawa aromatik yang berbeda dengan durian. Beberapa senyawa volatil baru muncul, misalnya asam oktanoat yang merupakan produk samping dari hidrolisis asam lemak yang memiliki flavor tengik. Beberapa senyawa volatil khas durian hilang, utamanya senyawa 
pembentuk rasa fruity (Neti et al., 2011). Penambahan asam sitrat pada produk pangan diketahui dapat menyebabkan rasa asam (Rotzoll et al., 2006). Sedangkan, korelasi tekstur terhadap asam sitrat pada produk sambal tempoyak ini belum dapat diketahui penyebabnya.

\section{KESIMPULAN}

Perlakuan penambahan asam sitrat dan lama sterilisasi serta interaksinya pada sambal tempoyak berkemasan retort memiliki pengaruh terhadap kadar air, $\mathrm{pH}$, aktivitas air, viskositas, dan tingkat kecerahan produk. Berdasarkan hasil penelitian yang telah dilakukan, diketahui bahwa sambal tempoyak berkemasan retort dengan perlakuan terbaik adalah sambal dengan penambahan asam sitrat $3 \%$ dan lama sterilisasi 35 menit.

\section{UCAPAN TERIMA KASIH}

Penelitian ini merupakan hasil pendanaan oleh Institut Teknologi Sumatera dalam kerangka program Hibah Penelitian ITERA Smart Tahun 2019 dengan Nomor Kontrak B/351/IT9.C1/PT.01.03/2019.

\section{DAFTAR PUSTAKA}

Al-Baali, A.G., Farid, M.M. 2006. Sterilization of Food in Retort Pouches. New York: Springer.

Amin, A.M., Z. Jaafar, dan N. L. Khim. 2004. Effect of Salt on Tempoyak Fermentation and Sensory Evaluation. Journal of Biological Sciences. Vol. 4(5): 650-653. doi:10.3923/jbs.2004.650.653.

Apichartsrangkoon, A., S. Srisajjalertwaja, P. Chaikham, dan S. Hirun. 2012. Physical and Chemical Properties of Nam Ping Noom, a Thai Green-Chili Paste, Following Ultra-High Pressure and Thermal Processes. High Pressure Research, An International Journal. Vol. 33 (1): 83-95. doi:10.1080/08957959.2013.765869.

Bindu, J., C.N. Ravishankar, dan T.K.S. Gopal. 2005. Shelf Life Evaluation of a Ready-To-Eat Black Clam (Villorita Cyprinoides) Product in Indigenous Retort Pouches. Journal of Food Engineering. Vol. 78 (3): 995-1000. doi:10.1016/j.jfoodeng.2005.12.040.

Catauro, P. M., dan M.H. Perchonok. 2011. Assessment of the Long-Term Stability of Retort Pouch Foods to Support Extended Duration Spaceflight. Journal of Food Science. Vol. 77(1), S29-S39. doi:10.1111/j.1750-3841.2011.02445.x.

Chaethong, K., R. Pongsawatmanit. 2015. Influence of Sodium Metabisulfite and Citric Acid in Soaking Process After Blanching on Quality and Storage Stability of Dried Chili. Journal of Food Processing and Preservation. Vol. 39 (6): 2161-2170. doi:10.1111/jfpp.12460.

Chuah, L., A.K. Shamil-Syuhada, M.T. Liong, A. Rosma, K.L. Thong, dan G. Rusul. 2016. PhysioChemical, Microbiological Properties of Tempoyak and Molecular Characterisation of Lactic Acid Bacteri Isolated from Tempoyak. Food Microbiology. Volume 58 (2016): 95-104. doi:10.1016/j.fm.2016.04.002.

Fellows, P. 2000. Food Processing Technology: Principles and Practice, Second Edition. Boca Raton: CRC Press.

Jiang, Y., J. Fu, G. Zanberman dan Y. Fuchs. 1999. Purification of Polyphenol Oxidase and the Browning Control of Litchi Fruit by Glutathiose and Citric Acid. Journal of the Science of Food and Agriculture. Vol. 79 (7): 950-954. doi:10.1002/(sici)1097-0010(19990515)79:7<950::aidjsfa289>3.0.co;2-e .

Gandjar, I. 2000. Fermentations of the Far East. Dalam: Robinson, R.K., C.A. Batt dan P.D. Patell. Encyclopedia of Food Microbiology. London: Academic Press.

Gardner, W.H. 1972. Acidulant in Food Processing. Dalam Furia, T. E. Hand Book of Food Additives. Cleveland: CRC Press.

Holanda, N.V., S.G. da Joyciane, M.L. dos S. Sandra, dan N.D. Marlene. 2018. Shelf Life of Artisanal Dei-Glace Sauce. Food Science and Technology Campinas. Vol. 38(3): 480-484. doi:10.1590/1678-457X.37416. 
Ibanoglu, S. dan P. Ainsworth. 2004. Application of Response Surface Methodology for Studying the Viscosity Changes During Canning of Tarhana, A Cereal-Based Food. Journal of Food Engineering. Vol. 64(3): 273-275. doi:10.1016/j.jfoodeng.2003.10.003.

Inchuen, S., P. Pornchaloempong, W. Narkrugsa, dan K. Tungkananuruk. 2011. Influence of Heat Treatment on Antioxidant Capacity and Color of Thai Red Curry Paste. Kasetsart J. (Nat. Sci.). Vol 45: 136-146.

Jannah, M., B.R. Handayani, B. Dipokusumo, dan W. Werdiningsih. 2018. Peningkatan Mutu dan Daya Simpan Ikan Pindang Kuning "Pindang Rumbuk" Dengan Perlakuan Lama Sterilisasi. Pro Food (Jurnal Ilmu dan Teknologi Pangan). Vol.4 No.1: 311-323. doi:10.29303/profood.v4i1.80

Leisner, J.J., M. Vancanneyt, G. Rusul, B. Pot, K. Lefebvre, A. Fresi, dan L.K. Tee. 2001. Identification of Lactic Acid Bacteria Constituting the Predominating Microflora in an AcidFermented Condiment (Tempoyak) Popular in Malaysia. International Journal of Food Microbiology. Vol. 63, Issue 1-2: 149-157. doi:10.1016/s0168-1605(00)00476-1

Lim, J. 2011. Hedonic Scaling: A Review of Methods and Theory. Food Quality and Preference. Vol. 22(8): 733-747. doi:10.1016/j.foodqual.2011.05.008.

Manolopoulou, E. dan T. Varzakas. 2011. Effect of Storage Conditions on the Sensory Quality, Colour and Texture of Fresh-Cut Minimally Processed Cabbage with the Addition of Ascorbic Acid, Citric Acid and Calcium Chloride. Food and Nutrition Science. Vol. 2 (9): 956-963. doi:10.4236/fns.2011.29130.

Neti, et al., I.D. Erlinda, dan V.G. Virgilio. 2011. The Effect of Spontaneous Fermentation on the Volatile Flavor Constituents of Durian. International Food Research Journal. Vol. 18: 635-641.

Pal, U.S., M. Das, R.N. Nayak, N.R. Sahoo, M.K. Panda, dan S.K. Dash. 2018. Development and Evaluation of Retort Pouch Processed Chhenapoda (Cheese Based Baked Sweet). Journal of Food Science and Technology. Vol. 56(1): 302-309. doi:10.1007/s13197-018-3490-6.

Pugliese, A., M.R. Loizzo, R. Tundis, Y. O’Callaghan, K. Galvin, F. Menichini dan N. O'Brien. 2013. The Effect of Domestic Processing on The Content and Bioaccessibility of Carotenoids from Chili Peppers (Capsicum Species). Food Chemistry. Vol. 141(3): 2606-2613. doi:10.1016/j.foodchem.2013.05.046

Rajan, S., V.V. Kulkarni, dan V. Chandirasekaran. 2014. Preparation And Storage Stability Of Retort Processed Chettinad Chicken. Journal of Food Science and Technology. Vol. 51: 173-177. doi:10.1007/s13197-011-0477-y.

Rasyid, H.N. 2004. Ensiklopedia Makanan Tradisional Indonesia (Sumatera). Kementerian Kebudayaan dan Pariwisata, Proyek Pelestarian dan Pengembangan Tradisi dan Kepercayaan.

Robertson, G.L. 2006. Food Packaging: Principles and Practice, Second edition. Boca Raton: CRC Press.

Robertson, G.L. 2009. Food Packaging and Shelf-Life: Practical Guide. Boca Raton: CRC Press.

Rojas-Graü, M.A., Solina-Fortuny dan O. Martin-Belloso. 2008. Effect of Natural Antibrowning Agents on Color and Related Enzymes in Fresh-Cut 'Fuji' Apples as an Alternative to the Use Ascorbic Acid. Journal of Food Science. Vol. 73: 267-272. doi:10.1111/j.17503841.2008.00794.x.

Rotzoll, N., A. Dunkel, dan T. Hofmann. 2006. Quantitative Studies, Tastereconstitution, and Omission Experiments on The Key Taste Compounds Inmorel Mushrooms (Morchella deliciosa Fr.). Journal of Agricultural and Food Chemistry. Vol. 54, 2705-2711. doi:10.1021/jf053131y.

Sahin, S. dan S.G. Sumnu. 2009. Advances in Deep-Fat Frying of Foods. Boca Raton: CRC Press.

Sausville, T.J. 1974. Acidulants. Dalam Johnson, A.H. dan M.S. Peterson. Encyclopedia of Food Technology, Westport Conn: AVI Publishing Co.

Sevenich, R., K. Reineke, P. Hecht, A. Frohling, C. Rauh, O. Schluter, and K. Dietrich. 2015. Impact of Different Water Activities (Aw) Adjusted by Solutes on High Pressure High Temperature Inactivation of Bacillus Amyloliquefaciens Spores. Microbiology. Vol. 6: 1-11. doi:10.3389/fmicb.2015.00689.

Topno, P. N., Vinothini, S.H. Jayaprakash, V. Varadaiah, S.H. Sheshagiri, P.M. Srinivas, dan M.M. Naidu. 2011. Ginger-Garlic Paste in Retort Pouches and Its Quality. Journal of Food Process Engineering. Vol. 36(1): 1-8. doi:10.1111/j.1745-4530.2011.00645.x.

Voon, Y. Y., N.S.A. Hamid, G. Rusul, A. Osman, dan S.Y. Quek. 2006. Physicochemical, Microbial and Sensory Changes of Minimally Processed Durian (Durio zibethinus cv. D24) During Storage 
Jurnal Teknologi Pertanian Andalas Vol. 24, No.2, September 2020, ISSN 1410-1920, EISSN 2579-4019

Hesti Ayuningtyas Pangastuti, Lasuardi Permana, Dea Tio Mareta, Vita Fitriani, dan Amalia Wahyuningty

at 4 and $28^{\circ} \mathrm{C}$. Postharvest Biology and Technology. Vol. 42(2), 168-175. doi:10.1016/j.postharvbio.2006.06.006.

Widawati, L., dan S. Efrianti. 2015. Preferensi Panelis dan Efektivitas Penggunaan Bahan Penstabil terhadap Mutu Sambal Hijau Tempoyak. Jurnal Aplikasi Teknologi Pangan. Vol. 4 No. 1: 42-47. doi:10.17728/jatp.2015.07.

Yuliana, N. 2005. Komponen Asam Organik Tempoyak. Komunikasi Singkat, Jurnal Teknologi dan Industri Pangan. Vol. XVI, No.1: 90-95.

Yuliana, N. 2007. Pengolahan Durian (Durio zibethinus) Fermentasi (Tempoyak). Jurnal Teknologi dan Industri Hasil Pertanian. Vol. 12(2): 74-80.

Yulistiani, R., Rosida, dan M. Nopriyanti. 2014. Evaluasi Proses Fermentasi pada Kualitas Tempoyak. J. Rekapangan. Vol. 8 (1): 84-103.

Zain, N.A.M., H.H. Harith, A.T. Olusesan, A.H. Zulkifli, F.A. Bakar, A. Osman, A.A. Hamid, and N. Saari. 2010. Level of Chemical and Microbiological Contaminations in Chili Bo (Paste). Journal Food Protein. Vol. 73(3): 541-546. doi:10.4315/0362-028X-73.3.541. 